\title{
Thinking Small in a Big Way
}

The successful integration of microfiche into the mainstream operations of a large scientific and technical research library over a ten-year period is outlined. Microfiche collection building, announcement, reading, and copying are discussed with some emphasis on the promotion of microfiche as a viable information source for library patrons. The use of COM for various internal processing functions is described. A recent user-satisfaction survey reveals that technical reports on microfiche are now accepted within Sandia Laboratories.

O

VER THE LAST TEN TO FIFTEEN YEARS that 4-by-6-inch piece of photographic film called a microfiche has been, in its library applications, roundly cursed, denigrated, appreciated, praised, and probably folded, spindled, and mutilated! The literature on microforms includes any number of basic texts $^{1,2}$ and discussions of the technical aspects of production and use, ${ }^{3}$ as well as accounts of specific applications in other institutions. $^{4-10}$

This paper examines the policies and practices developed by the Sandia Laboratories Technical Library to acquire, process, announce, and promote the use of the technical reports literature in microfiche format. We will also discuss a number of other applications of this information medium in the library.

Sandia Laboratories is operated by Sandia Corporation, a subsidiary of Western Electric, as a service to the U.S. government on a nonprofit, no-fee basis. Sandia serves as a prime contractor to the Department of Energy (DOE) with major responsibilities for the conduct of various national security and energy projects for DOE and several other federal agencies.

The Sandia Laboratories Technical Library has a staff of fifty people and functions as two divisions: information services and

John Gardner is a library resource analyst, and Gladys Rowe a subject specialist at the Sandia Laboratories Technical Library, Albuquerque, New Mexico. This work was supported by the U.S. Department of Energy. technical processes. Collections include approximately 38,000 books, more than half a million technical reports (of which more than 90 percent are on microfiche), and approximately 1,500 periodical subscriptions. More than 15,000 of our periodical volumes are in $16 \mathrm{~mm}$ microfilm.

The library collections are strong in the areas of aerospace, chemistry, energy conservation and utilization, materials, mathematics, nuclear technology, physics, and weapons research. For the last fiscal year the library's acquisitions budget was more than $\$ 310,000$. Almost all functions of the technical library are fully computerized.

\section{The Microfiche Collection}

The microfiche acquisition program began in 1969. Since then the library has acquired all technical reports on microfiche issued by the Atomic Energy Commission and subsequent related agencies-the Energy Research and Development Administration, the Nuclear Regulatory Commission, and the Department of Energy. We have also acquired technical reports on microfiche issued by the National Aeronautics and Space Administration (NASA) and its predecessor, the National Advisory Committee for Aeronautics (NACA). Since 1970 we have received technical reports on microfiche in selected subject categories from the $\mathrm{Na}$ tional Technical Information Service (NTIS). Recently we have acquired the complete microfiche collection of Power Reactor Dockets issued by the Nuclear Regulatory Commission; the complete collection of 
Bureau of Mines publications; and publications of the U.S. Congress on microfiche distributed by the Congressional Information Service. The total collection now amounts to more than half a million reports in microfiche format.

Much of this material is currently stored in three Remington Rand Lektrievers located close to the library circulation area. The collection expanded so rapidly that it became necessary to move the older microfiche to a nearby vaulted area where they are stored on shelves in cardboard file boxes.

Technical reports in microfiche are filed by the alphanumeric report number located in the upper left-hand corner of the microfiche. The only exceptions to this practice are the microfiche for Power Reactor Dockets. These are filed primarily by the name of the designated power plant and secondarily by the docket number.

At the time we began to collect technical reports in microfiche, we established a policy not to catalog or index any of the material. Consequently, references to microfiche are not included in our computerized reports catalogs. Instead we rely on the printed indexes published by DOE, NASA, and NTIS. When the number of the report is known, we refer directly to the microfiche collection.

\section{ANNOUNCEMENT AND DISTRIBUTION SERVICES}

Newly acquired microfiche are announced in the library's semimonthly announcement bulletins. Data on reports acquired from DOE, NASA, and NTIS are extracted from the NTIS bibliographic data file on magnetic tape. This tape extract is reformatted inhouse so that reports are grouped under the COSATI subject categories assigned by NTIS. A hard copy listing is then printed by a computer. The announcement bulletin, SCAN: Sandia Corporation Accession News, is prepared from this camera-ready copy by the Sandia printing services group (see figure 1).

SCAN has a circulation of 370 copies. An order form is included at the back of each issue. SCAN subscribers may order reports by annotating the accompanying order form with the report numbers they require and sending the form to the library circulation group. Circulation personnel then send master copies of the requested microfiche to the Sandia micrographics group, where duplicates are produced; the master copy and requested duplicates are returned to the library; and the library, in turn, sends the duplicate to the requester. No circulation record is kept of microfiche sent out in this manner. The requester retains the copy as long as needed.

We make no attempt to check the quality of either newly received or duplicated microfiche. However, personnel in the micrographics group are responsible for reviewing the material being copied. When they find microfiche of poor quality, they are responsible for indicating that the fiche is of such poor quality that it should not be copied or that certain pages are of inferior quality and the best available copy is being sent.

In these instances circulation personnel send the microfiche to the requester with one or the other of two special library forms developed to convey this information.

When hard copy is specifically requested in order to get clearer images, the library's reports acquisitions personnel often contact the original publisher of the report because the distributing agency has probably already sent the best copy it can produce.

We have found that microfiche of poor quality is usually created when the original report was probably never intended for conversion to microfilm format. This occurs most often when the originals are translations, conference papers, periodical articles, work typed on colored paper, or pages consisting of equations, photographs, charts, maps, diagrams, or reduced computer output.

In other instances the subcontractor responsible for preparation of the microfiche has done a poor job either in the preparation of the master or in the preparation of the second generation microfiche for multiple copy distribution. When this occurs, we request that the distributing agency look into the question of quality control with its subcontractor.

\section{USING THE MICROFICHE COLLECTION}

When we began our microfiche acquisi- 
32 USE OF GEOTHERMAL HEAT FOR CROP DRYING AND RELATED AGRICULTURAL APPLICATIONS. FINAL RFPORT. GORONN, T. J. WRIGHT, T. C. FEIN, E. MUNSON, T. R. RICHMONO, R. C. FUTURES GROUP, GLASTONBURY, CT. $\triangle O E P A R T M E N T$ OF ENFRGY. MAR $78.262 P$.

33 GREEN FACTORIES FOR LIQUID FUEL. CALVIN, 6. J. CALVIN, M. CALIFORNIA UNIV. BERKELEY. LAWRENCE BERTELEY
LAB, ODEPARTMENT OF ENERGY. APR 78. 19P. LBL-7584

34 PETROLEUM PLANTATIONS. CALVIN, M. CALIFORNIA UNIV., BERKELEY. LAMRENCE BERKELEY LAB. ODEPARTMENT OF ENERGYS APR TB. 41P. LBL -8236

35 PRODUCTION OF SUGARCANE AND TROPICAL GRASSES AS A RENEMABLE ENERGY SOURCE. THIRO OUARTERLY REPORT, DECEMBER 1. 1977--FEBRUARY 28, 1978. CEENTER FOR ENERGY ANO ENVIRONMENT RESEARCH, RIO PIEDRAS. PR. *DEPARTMENT OF ENERGY: 1978. 5SP. ORO-5422-3

36 ANALYSIS TO DEVELOP A PROGRAM FOR ENERGY CONSERVATION IN IRRIGATED AGRICUL TURE, CONF, B. W. BRIX, V. L. FAKIN, R, E, LAUGHLIN, B. M. BATTELLE PACIFIC NORTHUEST LABS., RICHLAND, WA. ODEPARTMENT OF ENERGY. "SEP 78. 95P. PNL.-2694.

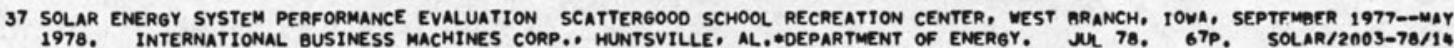

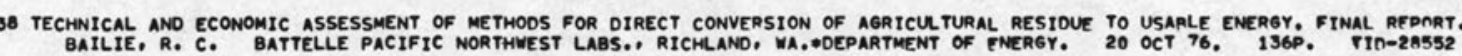

39 SEMIANNUAL PROGRESS REPORT FOR THE IDAHO GEOTHERMAL PROGRAM, APRIL 1--SEPTEMBER 30, 1978. BLAKE, 6. L. IDAHO NATIONAL ENGINEERING LAB., IDAHO FALLS, \#DEPARTMENT OF ENERGY. NOV 78. 99P. TREE-1295 40 USES OF WARMED WATER IN AGRICULTURE. FINAL REPORT. GARRETT, R. E. CALIFORNIA INIV., DAVIS. DEPT. OF AGRICIR.TURAL
ENGINEERING. WDEPARTMENT OF ENERGY. NOV 78. 59P. UCRL-13930

*onastronomy ano astrophysics 41 SOME COSMOLOGICAL CONSEQUENCE OF HADRON MATTER PHASE TRANSITION AT HIGH TEMPERATURE. BUGRII, A. I. TRUSHEVSKIT. AG A. 42 REVIEW AND INTERPRETATION OF RECENT COSMIC RAY BERYLLIUM ISOTOPE MEASUREMENTS. AUFFTNGTON, A. CALIFORNTA UNIV., 43 STEADY STATE MODELS FOR FILAMENTARY PLASMA STRUCTURES ASSOCIATED WITH FORCE FREE MAGNETIC WIELDS. MARKLUNO, 6.

-o*atmospheric sciences

44 ROCKET-BORNE MEASUREMENTS OF THE OAYSIDE CLEFT PLASMA THE TORDO EXPERIMENTS. MINNINGHAM, J. D. JEFFRIES, R. A. STENBAEK-NIELSEN, H. C. SPEISER, T. W. ROACH. W. H. TEXAS UNIV. AT DALLAS, RICHARDSON. CENTER FOR SPACE SCTENCES, *ATR

45 PROBLEMS IN THE CHEMISTRY OF METALLIC SPECIES IN THE D ANO E REgIONS. MURAD. EDMONO. AIR FORCE GEOPHYSICS LAES, $A 0-1064 \quad 482 / 35 L$

47 STUDIES OF THE DYNAMICS OF THE HIGH LATITUDE IONOSPHERE. RAITT, W. J. UTAH STATE UNIV. LOGAN. CENTER FOR ATMOSPHERIC 
tions program, we saw that extraordinary measures would be necessary to sell it as a viable information source. With the assistance of writers from the public relations group, we prepared a brochure designed to sell the concept to potentially unwilling users. A small but attractive four-page brochure was produced emphasizing the positive aspects of microfiche and instructing patrons in its use.

We stressed that more reports would be available; that they could be obtained quickly; that they never had to be returned; and, finally, that both the library and its patrons would save space. A detailed description of microfiche was presented, along with additional information on how it is read and obtained. Copies of the brochure were sent to every scientist and engineer in the laboratories. Library staff members were urged to be positive in recommending the use of microfiche and not to apologize for it.

Every effort was made to make things as easy as possible for patrons using this medium of information for the first time. Through a special budget allocation, we acquired more than 150 small, low-cost microfiche readers that were distributed to the most frequent users of the technical reports literature. We also acquired three reader/ printers that were sent to technical groups maintaining the largest collections of technical reports literature. Reader/printers were also made available in the library. More readers were later purchased and distributed to other users. A location-listing of readers and reader/printers was sent with every requested microfiche.

Finally, when computer-output-microfilm (COM) became a reality, Sandia Laboratories invited the major manufacturers of microfiche readers and reader/printers to exhibit their products in our auditorium. Invitations were also sent to Sandia personnel to review the equipment. A large number of interested scientists and engineers visited the exhibit and used the equipment under real-life conditions. We asked for opinions on which equipment would be most appropriate for their use. On the basis of this survey the laboratories standardized the purchase of microfiche readers and reader/printer equipment.

As technology has improved, other equipment has been studied and purchased. It is now available upon request through the office equipment group in much the same way as typewriters are issued. The standard readers are provided with twin lenses: one for $24 \times$ and the other for $48 \times$ reduction microfiche. The library presently provides four microfiche reader/printers with a variety of lenses for the use of its patrons in the library building.

Initially, reaction to the introduction of microfiche was one of grudging acceptance. An enormous amount of microfiche was undoubtedly converted into hard copy, either through the use of reader/printers, or by requesting blowback (i.e., an enlarged print made from a microimage) from the printing services group. To accommodate these requests, the printing services group acquired two step-and-repeat microfiche-to-hard-copy machines.

Our patrons have since found that it is not necessary to convert every sheet of microfiche, especially those reports of peripheral interest, to hard copy. Patrons frequently review microfiche reports on readers and then decide to convert only certain portions to hard copy or, perhaps, none at all. Just as with hard copy originals, a report is not necessarily useful just because the title sounds intriguing.

We do order hard copy reports if the requested report is more than 150 pages long or if it contains many maps, charts, photographs, illustrations, tables, graphs, or computer listings. Material of this kind is seldom legible in microfiche format. If the report is already in the microfiche collection, however, a duplicate of that microfiche is sent to the requester for review.

\section{OTHER APPLiCATIONS}

There are several other applications of microfiche in the Sandia Laboratories Technical Library. The library is responsible for the subsequent distribution of Sandia Laboratories technical reports-those reports that have been prepared by or for individuals within Sandia Laboratories.

In 1974 we initiated a program to convert hard copies of all newly published Sandia reports immediately to microfiche. All Sandia Laboratories reports are cataloged and entered into a master reports file, so it was 
a matter of programming to extract the basic information needed for the eye-legible portion of a microfiche from the cataloging entry for a given Sandia report.

This information is fed to a Datagraphics 4561 , and strips of eye-legible $35 \mathrm{~mm} \mathrm{mi-}$ crofilm listing the author, title, date, etc., are prepared and matched with the hard copy reports they represent. Each report and the $35 \mathrm{~mm}$ microfilm strip representing it are then sent to the micrographics group. The $35 \mathrm{~mm}$ strip becomes the eye-legible portion of the microfiche; the report itself is microfilmed on a page-by-page basis and formatted into the body of the microfiche. The hard copy report and its microfiche are then returned to the library, where they are filed separately.

At the time this project was inaugurated, we also started a retrospective program to convert to microfiche all Sandia reports published since 1962. This project, employing the same techniques, is almost completed. All Sandia reports published before 1962 are available in $16 \mathrm{~mm}$ microfilm.

The library also uses microfiche as a byproduct of many of its own internal processes. Almost all library functions are computerized-acquisitions, receiving, cataloging, and circulation of books and reports as well as the entire periodicals function. Some of the products from these systems are produced in hard copy form; others are produced in microfiche only. For example, our reports catalog is produced in microfiche; it is updated annually with both weekly and monthly supplements. The microfiche are housed in various rotary or desk stands placed next to microfiche readers or reader/printers. Many of the frequently updated tools associated with the circulation and periodicals functions are also received in COM.

\section{Assessing the Program}

How well have we succeeded in our use of microfiche? From the standpoint of the library, it was immediately obvious that the space savings were enormous. We estimated that in a given year the savings (in terms of linear footage) were the equivalent of the length of a football field, including both end zones. The conversion of Sandia reports to microfiche has saved an immense amount of room. Library staff members appreciate the ease of pulling a sheet of microfiche of an internal listing and referring to that on a handy reader rather than lugging around a stack of hard copy computer output.

But none of this makes much sense if in the end library users are not happy with the situation. Following our initial decision to adopt microfiche, our approach was that we were providing patrons with the information they needed or had requested, and the format was a secondary consideration.

Naturally, some patrons did not agree with this philosophy. The standard complaints were: "You can't write on microfiche"; "You can't browse through microfiche"; "Things are hard to find on microfiche"; or "With my bifocals it gives a crick in the neck!"

Since that time many scientists and engineers new to Sandia have joined the laboratories' staff. Many of them were already accustomed to using microfiche. The attitudes of longtime staff members have softened, and most of the recently arrived staff members had already accepted microfiche. Although it is not exactly welcomed with open arms, microfiche is now considered a fact of life.

In the first quarter of 1978 we undertook a comprehensive study of the use of technical reports by the laboratories staff. We set out to learn what kinds of people used technical reports, which subject areas were the most popular, degrees of satisfaction with reports received, the accessibility of microfiche readers, opinions concerning the useful life of a given report, and how the patron had heard about it. A large propor-

TABLE 1

USERS' REACTIONS TO REPORTS IN MiCROFICHE ForMat

\begin{tabular}{|c|c|c|c|}
\hline $\begin{array}{l}\text { For this particular } \\
\text { report were you } \\
\text { satisfied with: }\end{array}$ & & & \\
\hline & $\begin{array}{l}\text { Satisfied } \\
\text { (Percent) }\end{array}$ & $\begin{array}{l}\text { User Respon } \\
\text { Neutral } \\
\text { (Percent) }\end{array}$ & $\begin{array}{l}\text { nse } \\
\text { Dissatisfied } \\
\text { (Percent) }\end{array}$ \\
\hline $\begin{array}{l}\text { The form or type of } \\
\text { copy received? } \\
\text { The ease of getting it? } \\
\text { The timeliness of } \\
\text { getting it? } \\
\text { Its legibility? }\end{array}$ & $\begin{array}{l}76 \\
97.5 \\
94.5 \\
74\end{array}$ & $\begin{array}{r}14 \\
2 \\
\\
5 \\
18\end{array}$ & $\begin{array}{r}10 \\
.5 \\
.5 \\
8\end{array}$ \\
\hline
\end{tabular}


tion of the reports requested were on microfiche so it was possible to collect a considerable amount of solid information about current attitudes toward microfiche. The results of a portion of this survey related to user satisfaction are presented in table 1 .

Ninety percent of our users were either satisfied or neutral to the form or type of microfiche; 99 percent with the ease of getting a report on microfiche; 99 percent with the speed of getting a report on microfiche; and 92 percent with the legibility of the report on microfiche. More than 52 percent of our users have microfiche reading equipment actually in their office; 39 percent have readers at least in close proximity, whereas for 9 percent, location was inconvenient. Library management and staff members were considerably encouraged by these findings. We can only conclude that microfiche has arrived. It is a useful tool for librarians and for library patrons.

\section{REFERENCES}

1. Albert J. Diaz, ed., Microforms in Libraries: A Reader (Westport, Conn.: Microform Review, 1975).

2. Judy Fair, ed., Microforms Management in Special Libraries: A Reader (Westport, Conn.: Microform Review, 1978).

3. Albert R. Materazzi, Archival Stability of Microfilm-A Technical Review (Washington, D.C.: U.S. Govt. Print. Off., 1978).

4. Bill W. Campbell, "A Successful Microfiche Program," Special Libraries 62:136-42 (March 1971).

5. Bill W. Campbell, "Commentary on 'A Successful Microfiche Program,' " Special Libraries 62:29-30 (Jan. 1978).

6. Peter Hernon, "Use of Microforms in Academic Reference Collections and Services," Microform Review 6:15-18 (Jan. 1977).
7. Barbara Kunkel and others, "The Impact of Modern Technology on a Technical Library," in Information Revolution, Proceedings of the 38th ASIS Annual Meeting (Washington, D.C.: American Society for Information Science, 1975), p.91-92.

8. Wilda B. Newman and Michlean J. Amir, "Report Literature: Selecting versus Collecting," Special Libraries 69:415-24 (Nov. 1978).

9. Arthur Tannenbaum and Eva Sidhom, "User Environment and Attitudes in an Academic Microform Center," Library Journal 101:2139-43 (Oct. 15, 1976).

10. Gloria J. Zamora and Martha C. Adamson, "Looking Back at the Microfilm Decision: Expectations and Experiences," Special Libraries 70:179-81 (April 1979). 